\title{
Effect of alum and lime on phosphorus leachability from sewage sludge
}

\author{
Md. M. Mortula \& S. Atabay \\ American University of Sharjah, Sharjah, UAE
}

\begin{abstract}
Wastewater treatment plants generate large amounts of solid wastes on a regular basis. These waste solids contain a large amount of organic matter, nutrients and heavy metal. Existing knowledge has focused on cost intensive options for disposal of these waste solids. For this reason, the ability to adopt these technological means has been limited to large scale wastewater treatment plants. Due to lack of viable technological means, small and medium sized wastewater treatment plants dispose of solid waste in an unplanned way causing harm to the environment. One of the disposal practices is land based application (e.g. fertilizer). However, the application poses concerns of contaminants from heavy metals and nutrients. Therefore, there appears to be a growing necessity for finding appropriate technology to address the concerns related to leachability in sewage sludge. Alum treatment has the potential to reduce the leachability in sewage sludge, but alum treatment can reduce the $\mathrm{pH}$, so lime addition can control the $\mathrm{pH}$ for the sewage sludge. Previous studies conducted by the author showed that the alum and lime treatment can reduce the leachability of sewage sludge. However, the effect of alum and lime dosages was not investigated. The objective of this paper is to assess the effect of alum and lime treatment of waste solids for reduction of leachability in wastewater treatment residuals. Batch tests were conducted to evaluate the leachability of phosphorus. The sludge was treated with $10 \mathrm{~g} / \mathrm{l}, 20 \mathrm{~g} / \mathrm{l}$ and $30 \mathrm{~g} / \mathrm{l}$ of alum solutions and lime doses of $10 \mathrm{~g} / \mathrm{l}$, $20 \mathrm{~g} / \mathrm{l}$ and $30 \mathrm{~g} / \mathrm{l}$ to evaluate the effect of lime dosage on the leachability. The results indicated that $20 \mathrm{~g} / \mathrm{l}$ of alum treatment seemed to be the most effective in reducing phosphorus leachability. However, the increase in lime dosage reduced the phosphorus leachability, with $30 \mathrm{~g} / 1$ of lime provided the least phosphorus leachability.
\end{abstract}

Keywords: leachability, batch tests, sewage sludge, land based applications and phosphorus. 


\section{Introduction}

Wastewater treatment plants generate solid wastes on a regular basis. These waste solids (sewage sludge) contain large amounts of organic matter, nutrients and heavy metal [1]. When disposed, these materials leach unwanted quantities of nutrients and heavy metals, causing deterioration of aquatic and ecosystem health [2]. Common disposal practices are often troubled with the toxic substances from the sludge that leach out in the surface water and groundwater causing pollution [3-6]. Phosphorus is a concern in leaching as it can accumulate in water bodies and cause deterioration of aquatic habitat. Existing knowledge have focused on cost intensive options for disposal of these waste solids. For this reason, the ability to adopt these technological means was limited to large scale wastewater treatment plants. One of the growing disposal practices are land based application (e.g. fertilizer). However, the application poses concerns of contaminants from heavy metals and nutrients.

Leaching of substances is the dynamic process of substance transport in a water medium. Heavy metals and phosphorus leaching from sewage sludge can be dangerous to ecological system and also to humans [7].

Retention or release in soil depends on the physical and chemical properties of the soil and the phosphorus. Sewage sludge treatment methods and phosphorus removal processes can influence the availability of phosphorus [810]. Previous studies revealed an effect on inorganic phosphorus in soils attached with aluminum $[11,12]$. This is also indicative of reduced phosphorus leaching. Therefore, alum treatment of biologically treated sewage sludge can potentially reduce phosphorus leachability. Lime treatment of sewage sludge is also common. However, the effect of lime treatment on phosphorus leachability was not explored.

The objective of this paper is to assess the effect of alum and lime treatment of biologically treated sewage sludge for reduction of leachability. Laboratory based batch tests were conducted to observe the leachability of phosphorus.

\section{Materials and methods}

\subsection{Materials}

A bucket of untreated sewage sludge was collected from a local wastewater treatment plant. The treatment plant was an activated sludge based wastewater treatment plant. Alum and lime solutions of each $10 \mathrm{~g} / \mathrm{L}, 20 \mathrm{~g} / \mathrm{L}$ and $30 \mathrm{~g} / \mathrm{L}$ were used to treat the sludge. $500 \mathrm{ml}$ of the Alum solution and the $\mathrm{pH}$ was monitored. Then after, lime solutions of $50 \mathrm{ml}$ were added each time until a $\mathrm{pH}$ value of 7 was reached. The sludge sample was then dried in open air. Once dried, it has been used for subsequent experiments.

\subsection{Experimental setup}

Batch tests were conducted in a controlled environment in the lab to evaluate the used Erlenmeyer flask. For the batch test, five $250 \mathrm{ml}$ Erlenmeyer flasks were 
used. Five flasks were provided with $0 \mathrm{~g} / \mathrm{L}, 2 \mathrm{~g} / \mathrm{L}, 4 \mathrm{~g} / \mathrm{L}, 6 \mathrm{~g} / \mathrm{L}$ and $8 \mathrm{~g} / \mathrm{L}$ of treated sludge respectively. The flasks were then placed on the shake table for one hour and a half (the shaker was set at $450 \mathrm{~Hz}$ ). Phosphorus was tested after filtration of the leachate. After that the leachates was filtered into a separate storage bottle, and concentrated acid was used to make the $\mathrm{PH}$ of the water in the storage bottles around two. The storage bottles were then preserved at a temperature of 4 degrees Celsius to be used later for test of heavy metals.

\subsection{Analytical methods}

Phosphorus was measured using HACH spectrophotometer (DR5000). The ascorbic acid method was used based on standard methods. Temperature and $\mathrm{pH}$ was measured using standard $\mathrm{pH}$ probe. Turbidity was measured using $\mathrm{HACH}$ portable turibidimeter. Aluminum, chromium and copper were measured using HACH spectrophotometer (DR5000) based on standard available methods.

\section{Results and discussions}

\subsection{Effect of lime treatment}

Based on the experimental results, untreated sludge had a leachate concentration of up to $28.59 \mathrm{mg} / \mathrm{L}$ of phosphorus while Aluminum, chromium and copper concentrations were mostly low $(<0.02 \mathrm{mg} / \mathrm{L})$ as shown in Table 1 . However, with lime treatment $(10 \mathrm{~g} / \mathrm{L}-30 \mathrm{~g} / \mathrm{L})$, phosphorus concentration in the leachate was dropped to $0.936 \mathrm{mg} / \mathrm{L}$ as shown in Tables 2-4. It should be noted that phosphorus concentration dropped for all the sludge concentrations and the increase in lime concentration also reduced the phosphorus leaching.

Lime treatment however increased the aluminum concentration in the leachate. It may be due to availability of alum, not necessarily the availability of lime. With the increase of lime concentration, there was no significant change in the aluminum concentrations. However, the effect on chromium and copper was very insignificant.

Table 1: $\quad$ Leachate characteristics for untreated sludge.

\begin{tabular}{|l|c|c|c|c|c|}
\hline Sludge & $0 \mathrm{~g} / \mathrm{L}$ & $2 \mathrm{~g} / \mathrm{L}$ & $4 \mathrm{~g} / \mathrm{L}$ & $6 \mathrm{~g} / \mathrm{L}$ & $8 \mathrm{~g} / \mathrm{L}$ \\
\hline $\mathrm{pH}$ & 7.5 & 7.4 & 7.32 & 7.24 & 7.2 \\
\hline Temp. & 25.4 & 25.8 & 25 & 25 & 25 \\
\hline Turbidity(NTU) & 0.56 & 1.51 & 2.45 & 3.61 & 7.25 \\
\hline $\mathrm{Al}(\mathrm{mg} / \mathrm{L})$ & 0 & 0 & 0 & 0.012 & 0 \\
\hline $\mathrm{Cr}(\mathrm{mg} / \mathrm{L})$ & 0 & 0.017 & 0.009 & 0.015 & 0.01 \\
\hline $\mathrm{Cu}(\mathrm{mg} / \mathrm{L})$ & 0 & 0.01 & 0.01 & 0 & 0.01 \\
\hline $\mathrm{P}-\mathrm{PO} 4(\mathrm{mg} / \mathrm{L})$ & 0 & 7.99 & 12.29 & 28.59 & 28.19 \\
\hline
\end{tabular}


Table 2: $\quad$ Leachate characteristics for sludge treated with $20 \mathrm{~g} / \mathrm{L}$ of alum and $10 \mathrm{~g} / \mathrm{L}$ of Lime

\begin{tabular}{|l|c|c|c|c|c|}
\hline Sludge & $0 \mathrm{~g} / \mathrm{L}$ & $2 \mathrm{~g} / \mathrm{L}$ & $4 \mathrm{~g} / \mathrm{L}$ & $6 \mathrm{~g} / \mathrm{L}$ & $8 \mathrm{~g} / \mathrm{L}$ \\
\hline $\mathrm{pH}$ & 7.83 & 7.73 & 7.75 & 7.5 & 7.75 \\
\hline Temp. & 25 & 26 & 25 & 25 & 25 \\
\hline Turbidity(NTU) & 0.15 & 8.19 & 26.5 & 34.7 & 48.8 \\
\hline $\mathrm{Al}(\mathrm{mg} / \mathrm{L})$ & 0 & 0.268 & 0.215 & 0.563 & 0.334 \\
\hline $\mathrm{Cr}(\mathrm{mg} / \mathrm{L})$ & 0 & 0.006 & 0 & 0.015 & 0 \\
\hline $\mathrm{Cu}(\mathrm{mg} / \mathrm{L})$ & 0 & 0 & 0.01 & 0.01 & 0 \\
\hline $\mathrm{P}-\mathrm{PO} 4(\mathrm{mg} / \mathrm{L})$ & 0 & 5.27 & 13.02 & 14.62 & 20.12 \\
\hline
\end{tabular}

Table 3: $\quad$ Leachate characteristics for sludge treated with $20 \mathrm{~g} / \mathrm{L}$ of alum and $20 \mathrm{~g} / \mathrm{L}$ of Lime.

\begin{tabular}{|l|c|c|c|c|c|}
\hline Sludge & $0 \mathrm{~g} / \mathrm{L}$ & $2 \mathrm{~g} / \mathrm{L}$ & $4 \mathrm{~g} / \mathrm{L}$ & $6 \mathrm{~g} / \mathrm{L}$ & $8 \mathrm{~g} / \mathrm{L}$ \\
\hline $\mathrm{pH}$ & 7.78 & 7.88 & 8.23 & 7.95 & 7.96 \\
\hline Temp. & 25 & 25 & 25 & 25 & 25 \\
\hline Turbidity(NTU) & 0.32 & 4.54 & 17.7 & 16.7 & 37.4 \\
\hline $\mathrm{Al}(\mathrm{mg} / \mathrm{L})$ & 0 & 0.084 & 0.373 & 0.271 & 0.667 \\
\hline $\mathrm{Cr}(\mathrm{mg} / \mathrm{L})$ & 0 & 0.001 & 0 & 0.003 & 0 \\
\hline $\mathrm{Cu}(\mathrm{mg} / \mathrm{L})$ & 0 & 0 & 0 & 0 & 0.02 \\
\hline $\mathrm{P}-\mathrm{PO} 4(\mathrm{mg} / \mathrm{L})$ & 0 & 3.31 & 5.56 & 6.86 & 8.86 \\
\hline
\end{tabular}

Table 4: $\quad$ Leachate characteristics for sludge treated with $20 \mathrm{~g} / \mathrm{L}$ of alum and $30 \mathrm{~g} / \mathrm{L}$ of Lime.

\begin{tabular}{|l|c|c|c|c|c|}
\hline Sludge & $0 \mathrm{~g} / \mathrm{L}$ & $2 \mathrm{~g} / \mathrm{L}$ & $4 \mathrm{~g} / \mathrm{L}$ & $6 \mathrm{~g} / \mathrm{L}$ & $8 \mathrm{~g} / \mathrm{L}$ \\
\hline $\mathrm{pH}$ & 7.6 & 7.98 & 8.32 & 8.39 & 8.25 \\
\hline Temp. & 26 & 26.1 & 25 & 25 & 25 \\
\hline Turbidity(NTU) & 0.3 & 2 & 12.8 & 31.6 & 34.3 \\
\hline $\mathrm{Al}(\mathrm{mg} / \mathrm{L})$ & 0 & 0.123 & 0.341 & 0.877 & 0.723 \\
\hline $\mathrm{Cr}(\mathrm{mg} / \mathrm{L})$ & 0 & 0.014 & 0.004 & 0.004 & 0 \\
\hline $\mathrm{Cu}(\mathrm{mg} / \mathrm{L})$ & 0 & 0 & 0.04 & 0.04 & 0.07 \\
\hline $\mathrm{P}-\mathrm{PO} 4(\mathrm{mg} / \mathrm{L})$ & 0 & 0.936 & 2.2 & 3.245 & 3.5 \\
\hline
\end{tabular}

\subsection{Effect of alum treatment}

Experimental results indicated that alum treatment was able to reduce phosphorus leaching when treated at $10 \mathrm{~g} / \mathrm{L}$ and $20 \mathrm{~g} / \mathrm{L}$ of alum. However, at $30 \mathrm{~g} / \mathrm{L}$ of alum treatment the reduction in phosphorus leaching was not considerable. This indicates the effect of lime treatment to significant for reduction of phosphorus leachability more than alum treatment. However, with 
an increase in alum concentration during treatment increase the aluminum concentrations in the leachate. For chromium and copper, there was no significant effect observed.

Table 5: $\quad$ Leachate characteristics for sludge treated with $10 \mathrm{~g} / \mathrm{L}$ of alum and $20 \mathrm{~g} / \mathrm{L}$ of Lime.

\begin{tabular}{|l|c|c|c|c|c|}
\hline Sludge & $0 \mathrm{~g} / \mathrm{L}$ & $2 \mathrm{~g} / \mathrm{L}$ & $4 \mathrm{~g} / \mathrm{L}$ & $6 \mathrm{~g} / \mathrm{L}$ & $8 \mathrm{~g} / \mathrm{L}$ \\
\hline $\mathrm{pH}$ & 7.46 & 7.965 & 7.995 & 7.78 & 7.86 \\
\hline Temp. & 25 & 25 & 25 & 25 & 25 \\
\hline Turbidity(NTU) & 0.42 & 7.53 & 14.7 & 28.7 & 27.6 \\
\hline $\mathrm{Al}(\mathrm{mg} / \mathrm{L})$ & 0 & 0.155 & 0.373 & 0.2 & 0.644 \\
\hline $\mathrm{Cr}(\mathrm{mg} / \mathrm{L})$ & 0 & 0 & 0 & 0.03 & 0.022 \\
\hline $\mathrm{Cu}(\mathrm{mg} / \mathrm{L})$ & 0 & 0 & 0 & 0 & 0 \\
\hline $\mathrm{P}-\mathrm{PO} 4(\mathrm{mg} / \mathrm{L})$ & 0 & 2.81 & 2.96 & 8.76 & 9.81 \\
\hline
\end{tabular}

Table 6: $\quad$ Table 6: Leachate characteristics for sludge treated with $30 \mathrm{~g} / \mathrm{L}$ of alum and $20 \mathrm{~g} / \mathrm{L}$ of Lime.

\begin{tabular}{|l|c|c|c|c|c|}
\hline Sludge & $0 \mathrm{~g} / \mathrm{L}$ & $2 \mathrm{~g} / \mathrm{L}$ & $4 \mathrm{~g} / \mathrm{L}$ & $6 \mathrm{~g} / \mathrm{L}$ & $8 \mathrm{~g} / \mathrm{L}$ \\
\hline $\mathrm{pH}$ & 7.57 & 7.74 & 7.77 & 7.81 & 7.67 \\
\hline Temp. & 25 & 25 & 25 & 25 & 25 \\
\hline Turbidity(NTU) & 0.3 & 4.17 & 13.9 & 22.4 & 41.2 \\
\hline $\mathrm{Al}(\mathrm{mg} / \mathrm{L})$ & 0 & 0.149 & 0.204 & 0.421 & 0.94 \\
\hline $\mathrm{Cr}(\mathrm{mg} / \mathrm{L})$ & 0 & 0.013 & 0 & 0.005 & 0 \\
\hline $\mathrm{Cu}(\mathrm{mg} / \mathrm{L})$ & 0 & 0 & 0 & 0 & 0 \\
\hline $\mathrm{P}-\mathrm{PO} 4(\mathrm{mg} / \mathrm{L})$ & 0 & 3.18 & 7.43 & 8.48 & 15.98 \\
\hline
\end{tabular}

\section{Conclusions}

Alum and lime treatment of sewage sludge was able to reduce phosphorus leachability. However, lime treatment was more effective in reducing phosphorus leachability than alum treatment, and alum and lime treatment increased aluminum leachability from the sludge. The impact of other metals in the sludge was not significant. Future studies to evaluate the kinetic behavior would be able to evaluate the applicable treatment doses of alum and lime.

\section{Acknowledgements}

The author acknowledges the American University of Sharjah for providing the financial and institutional support to complete research work (FRG10-31). The author also acknowledges Kenan Jijakli and Ahmad Ghadban for their help in some of these experiments. 


\section{References}

[1] Metcalf and Eddy Inc., 2003. Wastewater Engineering: treatment and reuse. Published by McgrawHill, New York, USA, 1819 p.

[2] Abdullah, M.P., Baba, I., Sarmani, S., and Erdawati (1995), Distribution of aluminum from alum sludge in water and sediment. Marine freshwater research, 46:159-165.

[3] Benítez, E., Romero, E., Gómez, M., Gallardo-Lara, F., and Nogales, R., (2001), Biosolids and Biosolids-ash as Sources of Heavy Metals in a Plant-Soil System, Water, Air and Soil Pollution, 132 (1-2) pp. 75-87

[4] Monedero, M.A.S., Mondini, C., de Nobili, M., Leita, L. and Roig, A. (2004), Land application of bio solids. Soil response to different stabilization degree of the treated organic matter, Waste Management, 24(4) pp. 325-332

[5] Singh, R.P. and Agrawal, M. (2007), Potential Benefits and Risks of Land application of Sewage Sludge, Waste Management, 28(2) pp.347-358.

[6] Spinosa, L. (2001), Evolution of sewage sludge regulations in Europe, Water Science and Technology, 44(10), pp. 1-8.

[7] Davis, M.L., and Cornwall, D.A. (2008), Introduction to Environmental Engineering. McGrawhill International Edition.

[8] Frossard, E., Sinaji, S., and Dufour, P., 1996. Phosphorus in urban sewage sludges as assessed by isotopic exchange. Soil Science Society of America Journal 60: 179-184.

[9] Maguire, R.O., Sims, J.T., Dentel, S.K., Coale, F.J., and Mah, J.T., 2001. Relationships between biosolids treatment process and soil phosphorus availability. Journal of Environmental Quality, 30:1023-1033.

[10] Penn, C.J., and Sims, J.T., 2002. Phosphorus forms in biosolids amended soils and losses in runoff: Effects of wastewater treatment process. Journal of Environmental Quality 31:1349-1363.

[11] Beek, J., De Haan, F.A.M., and Van Reimsdijk, W.H., 1977. Phosphates in soils treated with sewage water. II. Fractionation of accumulated phosphates. Journal of Environmental quality, 6: 7-12

[12] Soon, Y.K., and Bates, T.E., 1982. Extractability and solubility of phosphate in soils amended with chemically treated sewage sludges. Soil Sciences, 134:89-96 